www.jmscr.igmpublication.org

Impact Factor 5.84

Index Copernicus Value: 83.27

ISSN (e)-2347-176x ISSN (p) 2455-0450

crossref DOI: _https://dx.doi.org/10.18535/jmscr/v5i7.211

\title{
To Study the Pattern of Adverse Drug Reaction Due to Cancer Chemotherapy in Regional Cancer Centre of a Tertiary Care Teaching Hospital in West Rajasthan
}

\author{
Authors \\ Amritpal Singh ${ }^{1}$, R.P.Acharya ${ }^{2}$, Rajvinder Kaur ${ }^{3}$ \\ ${ }^{1}$ M.D. Pharmacology ( $3^{\text {rd }}$ year), ${ }^{2}$ Sr.Prof. and Head, Department of pharmacology, S.P.M.C. Bikaner \\ ${ }^{3}$ District Hospital Ganganagar \\ Corresponding Author \\ Amritpal Singh \\ Email:dr_amritpal@rediffmail.com
}

\begin{abstract}
Background: Cancer, a term that elicits a shock in the nerve endings of every individual touches every country in the world.

Material and Method: It was a prospective observational study. The study was carried out between November 2015 to April 2016 conducted in medical Oncology \& Radiation Oncology Department in P.B.M. hospital and associated group of hospital, Bikaner.

Result: female 43(252) were more affected by ADR as compared to male patients 34 (164). anaemia (14.42\%) was the most common ADR followed by Vomiting (10.34\%) and Nausea $(9.13 \%)$.

Conclusion: Chemotherapeutic drugs have a narrow therapeutic index and the dosage needed to achieve a therapeutic response usually proves toxic to the body's rapidly proliferating cells.

Keywords: ADRs, Cancer, Chemotherapy.
\end{abstract}

\section{Introduction}

Cancer, a term that elicits a shock in the nerve endings of every individual touches every country in the world. ${ }^{1}$ Cancer incidences and death rates are rapidly increasing world widely as well as in India. $^{2}$

According to Global Cancer Network (GLOBOCAN) 2012 report, an estimated 14.1 million new cancer cases and 8.2 million cancerrelated deaths occurred in 2012. Prevalence estimates for 2012 show that there were 32.6 million people alive who had cancer diagnosed in the previous five years. The prevalence of cancer is expected to increase, it has been estimated that by the year 2030, there will be 22.2 million new cancer cases and over 13.1 million cancer deaths will occurs annually in the world. ${ }^{4}$

Cancer chemotherapy first introduced in the 1960s, before that surgery and radiation therapy was the only means of cancer treatment. ${ }^{14}$ Chemotherapeutic drugs have a narrow therapeutic index and the dosage needed to achieve a therapeutic response usually proves toxic to the body's rapidly proliferating cells. ${ }^{16}$ Adverse drug reactions (ADRs) are any noxious, unintended and undesired effects of a drug which 
occur at doses normally used in man for prophylaxis, diagnosis or treatment of disease, or for the modification of physiological function. ${ }^{17}$

The state wise distribution of different cancer patients in India shows that Rajasthan is among the most effected states of India due to various cancer. $^{20}$ Acharya Tulsi Regional Cancer Treatment \& Research Centre situated in P.B.M. hospital, Bikaner. Most of the cancer patients from catchment area come to Bikaner for treatment of various types of cancers. Considering the impact of ADRs on morbidity and mortality rates and the immense potentiality of cancer chemotherapeutic agents to produce a wide range of ADRs, studies to evaluate the incidence and nature of ADRs in this population was needed. It may also create awareness among the treating physicians. The previous studies of ADEs in cancer chemotherapy shows different aspect of ADRs, but studies in this regards in this region was lacking despite the fact that it covers such a large population from four to five states including Punjab , Hariyana ,UP and Bihar also. With this background the present study was designed.

\section{Material and Method}

It was a prospective observational study. The study was carried out between November 2015 to April 2016 conducted in medical Oncology \& Radiation Oncology Department in P.B.M. hospital and associated group of hospital, Bikaner. The study population involved patients who were on chemotherapy.

\section{Inclusion Criteria}

New Patients between 18 to 65 years of age from both genders who were receiving cancer chemotherapy from first cycle of chemotherapy and after wards.

\section{Exclusion Criteria}

Patients with drug reaction due to deliberate or unintentional over dosage, ADR due to alternate systems like Ayurveda, Homeopathy, Unani and drug reaction occurring due to prescribing and dispensing error were excluded from study. Patients who have received radiotherapy or prior chemotherapy and Pregnant and lactating females were also excluded.

Data of ADRs with detailed history were collected from the patients admitted in the Medical Oncology \& Radiation Oncology Department. Monitoring for adverse effects was done based on daily questioning of symptoms during their admission period in hospital. To record ADRs pre designed pre structured proforma containing questions regarding clinical history, demographic data, drug history, personal history, family history, present and past medical history, and history of allergy details of chemotherapy, presenting complaint, baseline laboratory investigations such as hemoglobin $(\mathrm{Hb})$, total counts, differential counts, renal function test, serum electrolytes and liver function test was used. Causality was assessed by both WHO Causality Assessment Scale and Naranjo's Algorithm. Preventability was assessed by Modified Schumock and Thornton scale. The severity of ADRs was assessed by modified Hartwig and Siegel scale.

No invasive investigation was undertaken or suggested to the treating physician as a part of the study. The drug effects which were described by the patients and effects which were diagnosed and reported were documented.

\section{Results}

Table 1: Patients Demographic: Gender

\begin{tabular}{|l|c|c|c|}
\hline Gender & No. of patient & No. of ADR & Percentage (\%) \\
\hline Male & 30 & 164 & $39.42 \%$ \\
\hline Female & 40 & 252 & $60.57 \%$ \\
\hline Total & 70 & 416 & $100 \%$ \\
\hline
\end{tabular}


The data collected on the ADR from the study site was analyzed into various parameters viz. type of ADR, probability, severity, preventability and detection of drugs implicated in the ADRs encountered. The results revealed that female 43(252) were more affected by ADR as compared to male patients 34 (164).

The findings indicate that the majority of patients, who encountered ADRs during the study period were in the age group of 51-60 years (32.86\%) followed by $41-50$ years $(27.43 \%)$ and 60 years and above $(22.85 \%)$. Incidence of ADRs was more in illiterate group (44.28\%). After analysing data we found that anaemia $(14.42 \%)$ was the most common ADR followed by Vomiting $(10.34 \%)$ and Nausea $(9.13 \%)$.

Table 2: Spectrum Of ADRs

\begin{tabular}{|l|c|c|c|c|c|c|}
\hline \multirow{2}{*}{ ADRs } & \multicolumn{2}{|c|}{ Male } & \multicolumn{2}{c|}{ Female } & \multicolumn{2}{c|}{ Total } \\
\cline { 2 - 7 } & No. & $\%$ & No. & $\%$ & No. & $\%$ \\
\hline Anemia & 24 & 14.63 & 36 & 14.28 & 60 & 14.42 \\
\hline Neutropenia & 7 & 4.2 & 14 & 5.56 & 21 & 5.04 \\
\hline Nausea & 16 & 9.75 & 22 & 8.73 & 38 & 9.13 \\
\hline Vomiting & 19 & 11.58 & 24 & 9.53 & 43 & 10.34 \\
\hline Abdominal pain & 7 & 4.26 & 15 & 5.95 & 22 & 5.28 \\
\hline Alopecia & 11 & 6.7 & 17 & 6.74 & 28 & 6.73 \\
\hline Rash & 7 & 4.26 & 12 & 4.76 & 19 & 4.56 \\
\hline Headache & 11 & 6.7 & 24 & 9.53 & 35 & 8.41 \\
\hline
\end{tabular}

Table 2 shows presenting complaints and adverse drug reaction causes by different drug regimen during cancer chemotherapy found in this study. After analysing data we found that anaemia (14.42\%) was the most common ADR followed by Vomiting $(10.34 \%)$ and Nausea $(9.13 \%)$.

\section{Discussion}

Chemotherapy has proven to extend life and prevent disease recurrence. Despite these therapeutic successes, many of the antineoplastic drugs has narrow therapeutic index and a high potential for causing adverse effects such as nausea/vomiting, neutropenia/ anemia/ pancytopenia, alopecia, constipation/ diarrhea, and fatigue/tiredness.

In gender distribution, majority of the study subjects were females $(60.57 \%)$ indicating higher incidence of ADR in females which is in consistence with earlier studies like Gunaseelan et al (60.7\%), Ajitha Sharma et al (55.9\%) and Deepti Chopra et al (73.6\%) . On the contrary, there are studies like Yash N.Goyal et al (54.29\%), Sunil Bellare et al $(55.3 \%)$ and Anju Prasad et al $(53 \%)$ where males were found to have more number of ADRs as compared to females.

Age of the subjects ranged from 18 years to 65 year and the mean age was 51.6 year with standard error of mean is 10.75 . Majority of the study subjects were in the age group of 51-60 year $(32.86 \%)$ which is in accordance with previous study done by Yash N.Goyal et al, Ajitha Sharma et al and Anju Prasad et al. In present study the incidence of ADRs among elderly and older adults was significantly higher than other age groups. This may be due to the low metabolizing capacity and reduced excretory functions leading to accumulation of drugs in the body and thus increasing the risk of ADRs. ${ }^{21}$ As a result extra precautions should be taken while using chemotherapy in the elderly population.

Commonest ADRs found in present study were Anaemia (14.42\%) vomiting (10.34\%) and nausea (9.13\%). Few other studies like Deepti Chopra et al, Yash N.Goyal et al and Anju Prasad et al reported nausea and vomiting as the most common ADR. Studies carried out by Ajitha Sharma et al reported Infection $(22.4 \%)$ as the most common ADR, while study conducted by 
Sunil Bellare et al reported Alopecia (27.76\%) to be commonest ADR. Cancer chemotherapy damages rapidly dividing cells of bone marrow resulting in myelosuppression thus affecting white blood cells, platelets and red blood cells. This myelosuppression leads to anemia and lowering of immunity. Nausea and vomiting are prominent with most cytotoxic agents and is caused mainly due to direct stimulation of chemoreceptor trigger zone.

\section{Conclusion}

Chemotherapeutic drugs have a narrow therapeutic index and the dosage needed to achieve a therapeutic response usually proves toxic to the body's rapidly proliferating cells. However, early detection of drug toxicity helps to modify the doses or the drug regimen to minimize toxic effects.

\section{Bibliography}

1. Jemal A, Bray F, Center MM, Ferlay J, Ward E, Forman D. Global cancer statistics. Cancer J Clin 2011 Mar-Apr; 61(2):69-90.

2. Javed, S., Ali, M., Sadia, S., Aslam, M.A., Masood, A.I., Shaikh, R.S. and Sayyed, A.H. Combined Effect of Menopause Age and Genotype on Occurrence of Breast Cancer Risk in Pakistani Population. Maturitas 2011;69: 377-382.

3. Mark Kirstein. Neoplastic Disorders and their treatment: General Principles, Section 19, Chapter 88-2. In: Applied Therapeutics; The Clinical Use of Drugs, $9^{\text {th }}$ Ed. Lippincott Williams and Wilkins. 2009

4. World Health Organization (WHO). World Cancer Report 2014: Cancer Fact sheet N²97. 2014.

5. Parkin DM. The global health burden of infection-associated cancers in the year 2002. International Journal of Cancer, 2006; 118:3030-304

6. Dikshit R, Gupta PC, Ramasundarahettige $\mathrm{C}$, et al. Cancer mortality in India: a nationally representative survey .Lancet 2012;379(9828):1807-16

7. National Cancer Registry Programme. Consolidated report of the population based cancer registries1990-1996. New Delhi: Indian Council of Medical Research; 2001.

8. Sarnath D, Khanna A. Current Status of Cancer Burden:Global and Indian Scenario.Biomedical Res J.2014;1(1):1-

9. Government of india,Ministry of health and family welfare;Department of health and family welfare;Lok sabha Starred question no. 98 http://admin.indiaenvironmentportal.org.in /files/file/cancer\%20cases.pdf

10. http://www.ey.com/Publication/vwLUAss ets/EY-expanding-cancer-care-in-india Call-for-action Date of access: 5 july2016

11. Patrick J. Medina. Cancer treatment and chemotherapy. In: Joseph T.Dipiro, Gary C.Yee editors. Pharmacotherapy - A Pathophysiologic Approach, 7th edition. United States: McGraw - Hill 2008:p. 2085- 2116.

12. Joel G. Hardman. Chemotherapy of neoplastic diseases. In: Goodman \& Gilman's. The Pharmacologic Basis of Therapeutics. 9th edition. McGraw-Hill, New York. p. 1381-1388

13. Tripathi KD. Anticancer drugs. Essentials of medical pharmacology. 7th ed. New Delhi: Jaypee 2013: 857-877

14. Stohr W, Paulides M, Bielack S, Jurgens $\mathrm{H}$, Koscielniak E, Rossi $\mathrm{R}$, et al. Nephrotoxicity of cisplatin and Carboplatin in sarcoma patients: a report from the late effects surveillance system. Pediatric Blood Cancer 2007; 48(2):140-7.

15. Goodman Gilman's The Pharmacological Basis of Therapeutics. 12th ed. New York: McGraw-Hill 2011 :p.1667

16. Classen DC, Pestotnik SL, Evans RS, Lloyd JF, Burke JP. Adverse drug events 
in hospitalized patients. J Am Med Assoc 1997; 277:301-6.

17. Lee A, Thomas SHL . Adverse drug reactions. In: Clinical Pharmacy and Therapeutics Roger. ( $3^{\text {rd }}$ ed), Churchill Livingstone, Spainp 2003:33-34.

18. Passarelli MCG, Filho WJ. Adverse drug reaction in elderly patients: how to predict them? Einstein 2007; 5(3):246-251

19. Kirthi C, Afsal A, Reddy M, Ali AS, Aparna Y, Sharma S. A study on the adverse drug effects of anti-cancer drugs in an oncology center of a tertiary care hospital. Int J Pharm Sci 2014;6:580-3.

20. Cancer Therapy .Cancer Scenario in India with Future Perspectives 2011;8:56-70.

21. Bates, D.W. and Leape, L. Adverse Drug Reaction. In: Morreli's Clinical Pharmacology. Boston: McGraw-Hill 2012. pp. 1223-1257.

22. Sunil Bellare et al.Adverse Drug Reaction due to Cancer Chemotherapy Journal of Young Pharmacists 2016;8(3):71-74.

23. Sasmi MB. Adverse drug reaction profile of cisplatin-based chemotherapy regimen in a tertiary care hospital in India. Int $\mathrm{J}$ Basic Clin Pharmacol 2015;4:1214-9.

24. Kaur K, et al. Spontaneous adverse drug reaction monitoring in oncology: Our experience. Indian J Cancer 2015;52:46770

25. Goyal Y N et al. Pattern of adverse drug reaction due to cancer chemotherapy in tertiary care teaching hospital in Gujarat. IJSR- international journal of scientific research 2014;3 (1):2277 - 8179 . 